\title{
Description of a xenoma-inducing microsporidian, Microgemma tincae n. sp., parasite of the teleost fish Symphodus tinca from Tunisian coasts
}

\author{
Lamjed Mansour ${ }^{1,2}$, Gérard Prensier ${ }^{1}$, Souâd Ben Jemaa ${ }^{2}$, Oum Kalthoum Ben \\ Hassine $^{2}$, Guy Méténier ${ }^{1}$, Christian P. Vivarès ${ }^{1}$, Emmanuel Cornillot ${ }^{1, *}$ \\ ${ }^{1}$ Parasitologie Moléculaire et Cellulaire, UMR 6023 CNRS - Université Blaise Pascal, Campus Universitaire des Cézeaux, \\ Bâtiment Biologie A, 63177 Aubière cedex, France \\ ${ }^{2}$ Biologie et Ecologie des Organismes Aquatiques, Bâtiment de Biologie, Faculté des Sciences, \\ Université de Tunis El Manar, 2092 Tunis, Tunisia
}

\begin{abstract}
A xenoma-inducing microsporidian species was found to infect the liver of the teleost fish, peacock wrasse Symphodus (Crenilabrus) tinca. Minimal estimates of the prevalence of the parasite in fishes caught along Tunisian coasts were as high as $43 \%$ for Bizerte samples (over 2 yr) and $72 \%$ for Monastir samples (over 3 yr). Developmental stages were dispersed within a xenoma structure that was bounded only by the plasma membrane of the hypertrophic host cell. Ultrastructural features support allocation to the genus Microgemma Ralphs and Matthews, 1986. Meronts were multinucleate plasmodia and were surrounded by rough endoplasmic reticulum (RER) of the host cell. Merogonic plasmodia developed into sporogonic plasmodia, with loss of the RER interface. Sporogony was polysporoblastic. Ovocylindrical spores $(3.6 \times 1.2 \mu \mathrm{m})$ harbored a lamellar polaroplast and a polar tube that was coiled 9 times. Spore features and host specificity led us to propose a new species, Microgemma tincae. The conversion of $M$. tincae xenomas into well-visible cyst structures or granulomas reflected an efficient host response involving the infiltration of phagocytic cells, degradation of various parasite stages and formation of a thick fibrous wall. The small subunit rDNA gene of $M$. tincae was partially sequenced. Phylogenetic analysis confirms the placement within the family Tetramicriidae represented by the genera Tetramicra and Microgemma.
\end{abstract}

KEY WORDS: Microsporidia $\cdot$ Microgemma tincae $\cdot$ Ultrastructure $\cdot$ Small subunit rDNA $\cdot$ Symphodus tinca $\cdot$ Xenoma $\cdot$ Tunisian coasts

Resale or republication not permitted without written consent of the publisher

\section{INTRODUCTION}

The phylum Microspora Sprague, 1977 is a group of obligate intracellular eukaryotic parasites that infect members of all major animal taxa. More than 1400 microsporidian species are distributed among about 150 genera (Larsson 1999). Some of these are human parasites that can be responsible for diseases in immunocompromised human patients (Bryan \& Schwartz 1999). However, the most common vertebrate hosts are fish. The diversity and phylogeny of fish microsporidians have been thoroughly reviewed (Lom 2002, Lom \& Nilsen 2003). An increased interest in their study is justified by the ability of some microsporidia to cause severe pathologies in wild and farmed fishes, e.g. Glugea hertwigi Weissenberg, 1911, a parasite of rainbow smelt fish; Microgemma hepaticus Ralphs and Matthews, 1986 infecting the liver of juvenile grey mullet; and Nucleospora salmonis Hedrick, Groff and Baxa, 1991, an intranuclear parasite of salmon (Shaw \& Kent 1999, Lom \& Nilsen 2003)

Fish-infecting microsporidia are found in different tissues and organs, and are currently represented by a total number of 157 species from 15 genera (Lom 2002, Azevedo \& Matos 2003). Ten genera are known to induce xenoma formation. The term xenoma accounts for a symbiotic complex characterized by a dramatic accumulation of parasite stages within the cytoplasm 
of a single hypertrophic host cell (Weissenberg 1949). The xenoma topology is variable according to the parasite and host species. In a recent attempt to classify fish-infecting microsporidia on the basis of the organization and physiology of the xenoma, it was concluded that the xenoma structure is a relevant criterion for only a few genera (Lom \& Nilsen 2003). However, the focus of infection remains a useful element for species diagnosis, especially when the xenoma can be observed by the naked eye, e.g. for Spraguea lophii Doflein, 1898, a parasite of Lophius spp. (Loubès et al. 1979), or Glugea atherinae, a parasite of Atherina boyeri (Berrebi \& Bouix 1978). Another criterion is the tissue tropism of the infection, e.g. the central nervous system for Spraguea (Loubès et al. 1979), muscles for Pleistophora (Canning \& Nicholas 1980) and Kabatana (Lom et al. 1999, 2000), connective tissue for Glugea (Moniez 1887), oocytes for Ovipleistophora (Pekkarinnen et al. 2002), gills for Loma (Morrison \& Sprague 1981) and liver for Microgemma (Ralphs \& Matthews 1986). A phylogenetic study based on small subunit (SSU) rDNA data has led to the distinction of 5 major groups of fish-infecting microsporidia, with these groups representing either families, superfamilies or higher taxa (Lom \& Nilsen 2003). For example, Group 3 is restricted to a single family divided into 3 clades (clades 1, 2 and 3), whereas Group 4 appears as a superfamily comprising 2 known families (Spragueidae, Tetramicriidae) and an additional clade (clade 4: Kabatana and Microsporidium seriolae).

Within the context of an evaluation of the impact of microsporidians on fishery off the Tunisian coasts of the Mediterranean Sea, a new species was identified in the liver of the teleost fish, peacock wrasse Symphodus (Crenilabrus) tinca Linnaeus, 1758 (family Labridae). Here, we present developmental and ultrastructural features of this parasite, with special emphasis on the evolution of the focus of infection. The proposed assignment to the genus Microgemma (family Tetramicriidae) is in agreement with a comparative analysis of partial SSU rDNA sequences.

\section{MATERIALS AND METHODS}

Sampling. Fish were captured by fishermen in boats working off the Tunisian coast near the towns of Monastir $\left(35^{\circ} 46.7^{\prime} \mathrm{N}, 10^{\circ} 50.1^{\prime} \mathrm{E}\right)$ and Bizerte $\left(37^{\circ} 16.4^{\prime} \mathrm{N}\right.$, $9^{\circ} 53.2^{\prime} \mathrm{E}$ ) (Fig. 1). About $80 \%$ of fishes were caught near Monastir during 4 sampling programs over $3 \mathrm{yr}$ (from 2001 to 2003), the remainder near Bizerte during 3 sampling programs over a period of $2 \mathrm{yr}$ (from 2002 to 2003). Fishes belonging to the species Synphodus tinca were subjected to a thorough examination of the liver by a stereomicroscope, in order to detect possible foci of infection. Pieces of liver were either fixed immediately for cytological work or preserved in $1 \times$ phosphate buffer saline solution (PBS) for spore purification and later DNA extraction.

Light microscopy and transmission electron microscopy. Liver fragments were fixed with $2.5 \%$ glutaraldehyde in $0.1 \mathrm{M}$ sodium cacodylate buffer ( $\mathrm{pH}$ 7.3) and postfixed with $1 \%$ osmium tetroxyde in the same buffer for $1 \mathrm{~h}$. Samples were then washed 3 times in cacodylate buffer, dehydrated in increasing concentrations of ethanol and embedded in Epoxy resin via propylene oxide. Sections were performed with a Leica Ultra-cut S ultra-microtome. For light microscopy, semi-thin sections were stained with $0.2 \%$ Azur Blue II, pH 8.5. Ultra-thin sections were routinely stained with uranyl acetate and lead citrate, and then examined with a Jeol 1200 EX electron microscope.

Spore purification and DNA extraction. Spores were mechanically released from liver pieces using 5 to 10 manual strokes of a Potter homogenizer (size no. 22, 0.005 to 0.007 inch clearance, Kontes-Gerresheimer). After washing several times in $1 \times$ PBS to eliminate contaminants of host origin, the spores were purified by filtration through $0.5 \mathrm{~g}$ of glass wool. DNA extraction was carried out on purified spores with the Elu-QUIK kit (Schleicher \& Schuell) according to the recommendations of the supplier. DNA was eluted in $50 \mu \mathrm{l}$ of TE $(1 \mathrm{mM}$ Tris, 0.1 mM EDTA) buffer $\mathrm{pH} 8$ and stored at $-20^{\circ} \mathrm{C}$.

PCR amplification. On the basis of the alignment of sequences available in the SSU rDNA database (http:// www.psb.ugent.be/rRNA/ssu) and of a compilation of eukaryotic primers (http://www.psb.ugent.be/rRNA/ primers/NS_lst.html), 2 degenerated primers were designed to offer a better specificity for microsporidia:

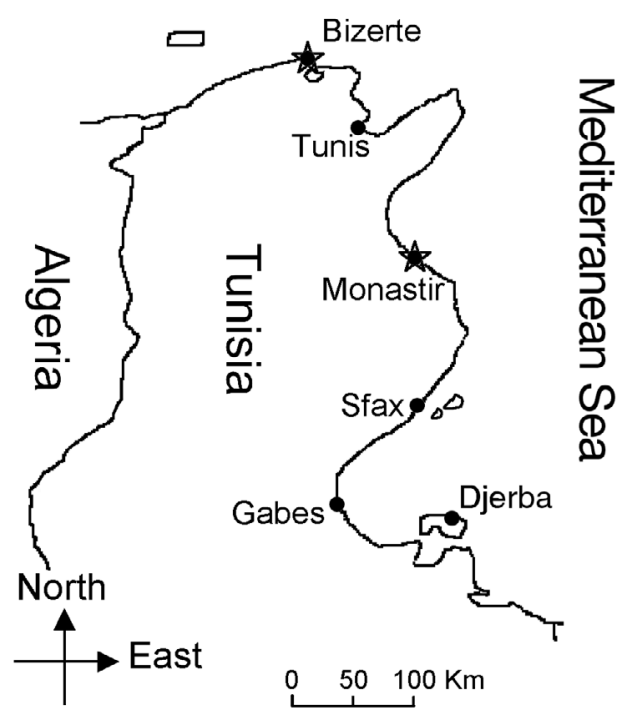

Fig. 1. Map of Tunisia showing the localities of the collected samples; Monastir (South) and Bizerte (North) marked by stars 
Table 1. Accession number and coordinates in SSU rDNA database entry for microsporidia used for multiple alignment and phylogenetic tree construction. Sequences are sampled in all groups to provide an overview of the diversity of fish infecting microsporidia. Organisms of Group 4 (Lom \& Nilsen 2003) are overrepresented to focus on the branching of Microgemma tincae

\begin{tabular}{|llr|}
\hline Organism & $\begin{array}{c}\text { Accession } \\
\text { number }\end{array}$ & $\begin{array}{c}\text { Coord- } \\
\text { inates }\end{array}$ \\
\hline $\begin{array}{llr}\text { Loma embiotocia } \\
\text { Loma acerinae }\end{array}$ & AF320310 & $1-828$ \\
Ichthyosporidium sp. & AF356224 & $28-843$ \\
Glugea atherinae & L39110 & $28-843$ \\
Glugea anomala & U15987 & $28-847$ \\
Pleistophora typicalis & AF044391 & $28-844$ \\
Ovipleistophora mirandellae & AF352956 & $26-859$ \\
Heterosporis anguillarum & AF387331 & $28-865$ \\
Spraguea sp. & AY465876 & $28-849$ \\
Spraguea lophii LP & AF104086 & $23-840$ \\
Spraguea lophii & AF033197 & $28-842$ \\
Microgemma caulleryi & AY033054 & $24-851$ \\
Tetramicra brevifilum & AF364303 & $23-833$ \\
Microgemma sp. & AJ252952 & $26-838$ \\
Microgemma tincae & AY651319 (this study) & $31-843$ \\
Kabatana takedai & AF356222 & $28-851$ \\
Nucleospora salmonis & U78176 & $10-782$ \\
\hline
\end{tabular}

SF4m (5' CACCAGGTTGATYCTGCCTRD 3') and SR1147m (5' TGTRGTRAICYTCCGYCAATY 3'). The expected size of the amplicon was approximately 840 bp. Amplification was carried out in $50 \mu \mathrm{l}$ reaction using 5 pmoles of each primer, $0.2 \mathrm{mM}$ of each dNTP, $5 \mathrm{U}$ of GoTag ${ }^{\mathrm{TM}}$ polymerase in $1 \times$ supplied buffer (Promega) and 1 to $10 \mathrm{ng}$ of genomic DNA. The reactions were run with a PerkinElmer thermocycler for 35 cycles of $94^{\circ} \mathrm{C}$ for $30 \mathrm{~s}, 56^{\circ} \mathrm{C}$ for $20 \mathrm{~s}$ and $72^{\circ} \mathrm{C}$ for $40 \mathrm{~s}$, followed by a final extension at $72^{\circ} \mathrm{C}$ for $10 \mathrm{~min}$. PCR products were visualized by running a $5 \mu \mathrm{l}$ aliquot on a $1 \%$ agarose gel and then cleaned using the QIAquick ${ }^{\circledR}$ PCR purification Kit (QIAGEN) according to the handbook protocol.

Cloning and DNA sequencing. Purified PCR products were inserted into the pGEM®-T Easy Vector system (Promega) and cloned in competent XL1-Blue Escherichia coli cells. From each cloned PCR product, 2 or 3 positive clones were selected for sequencing. The sequence reaction was run in a PerkinElmer thermocycler with $5 \mu$ of CEQ Dye Terminator Cycle Quick Start Master Mix (Beckman Coulter). Five different primers were used in order to obtain the whole sequence in both directions: SSR530 (Weiss \& Vossbrinck 1998), SP6, T7, SF4m and SR1147m. DNA sequencing was performed with a CEQ 2000 capillary sequencer (Beckman Coulter).
Sequence assembly and phylogenetic analysis. Sequence data were stored in the AceDB database (Durbin $\&$ Mieg 1991). Trace clipping (vector and quality) and assembly were done with an Acembly platform on SUN ultra 5 with Solaris UNIX operating system. A search for sequence similarities was carried out using the Basic Local Alignment Search Tool (Blastn) from NCBI BLAST web portal (www.ncbi.nlm.nih.gov/BLAST). The consensus sequence of high quality selected for further multiple alignments was 813 bp in length (from base 31 to base 843). Similar SSU rDNA regions of other microsporidia were extracted from GenBank DNA entries. Sixteen sequences selected for phylogenetic analysis (Table 1) were from species assigned to Group 4 and a few representatives of the 4 other groups of fish-infecting microsporidia (Lom \& Nilsen 2003). The tree was generated by the neighbor joining (NJ) method implemented in CLUSTALW software (Thompson et al. 1994) available at the INFOBIOGEN deambulum web portal (www.infobiogen.fr/services/deambulum/fr/). The bootstrap was based on 1000 samples and 111 randomizations.

\section{RESULTS}

\section{Prevalence of the microsporidia infecting Symphodus tinca}

We examined the liver from 234 fishes of the species Symphodus tinca. Ranging in size from 12.7 to $29 \mathrm{~cm}$, these fishes were divided into 6 different classes, each covering a size range of $3 \mathrm{~cm}$ (Table 2). The smallest

Table 2. Frequency and intensity of the microsporidian infection of Symphodus tinca in relation to fish size for Monastir and Bizerte

\begin{tabular}{|c|c|c|c|c|c|c|}
\hline \multirow{3}{*}{$\begin{array}{l}\text { Locality } \\
\text { Fish size (cm) } \\
\text { Monastir }\end{array}$} & \multirow{3}{*}{$\begin{array}{l}\text { No. of } \\
\text { fishes }\end{array}$} & \multirow{2}{*}{\multicolumn{2}{|c|}{$\begin{array}{l}\text { Infected fishes } \\
\text { No. Frequency }\end{array}$}} & \multicolumn{3}{|c|}{ Parasite charge ${ }^{a}$} \\
\hline & & & & \multicolumn{3}{|c|}{ Low Medium High } \\
\hline & & & & & & \\
\hline $12.5-15.5$ & 45 & 41 & 0.911 & 11 & 15 & 19 \\
\hline $15.5-18.5$ & 93 & 72 & 0.774 & 45 & 28 & 20 \\
\hline $18.5-21.5$ & 34 & 18 & 0.529 & 26 & 8 & 0 \\
\hline $21.5-24.5$ & 10 & 0 & 0 & 10 & 0 & 0 \\
\hline $24.5-27.5$ & 4 & 3 & 0.750 & 3 & 1 & 0 \\
\hline $27.5-30.5$ & - & - & - & - & - & - \\
\hline Total & 186 & 134 & 0.720 & 95 & 52 & 39 \\
\hline \multicolumn{7}{|l|}{ Bizerte } \\
\hline $12.5-15.5$ & 2 & 2 & 1 & 1 & 0 & 1 \\
\hline $15.5-18.5$ & 13 & 8 & 0.615 & 8 & 4 & 1 \\
\hline $18.5-21.5$ & 12 & 7 & 0.583 & 11 & 1 & 0 \\
\hline $21.5-24.5$ & 11 & 3 & 0.273 & 9 & 2 & 0 \\
\hline $24.5-27.5$ & 7 & 1 & 0.143 & 7 & 0 & 0 \\
\hline $27.5-30.5$ & 3 & 0 & 0 & 3 & 0 & 0 \\
\hline Total & 48 & 21 & 0.430 & 39 & 7 & 2 \\
\hline
\end{tabular}


specimens were underrepresented because fishing techniques and ill-defined biological features of $S$. tinca meant they were difficult to catch. Both median and mean values for the size distribution of the Monastir specimens $(17.2 \mathrm{~cm}$ and $17.48 \mathrm{~cm}$, respectively) are lower than those for Bizerte $(20.4 \mathrm{~cm}$ and $20.94 \mathrm{~cm})$. Individuals of the smallest size class $(12.5$ to $15.5 \mathrm{~cm})$ are particularly rare in the Bizerte site $(\sim 4 \%)$ while they represent $\sim 24 \%$ of the total population from the Monastir site.

The frequency of fishes with a liver containing at least 1 microsporidian cyst, as detected with a stereomicroscope, was calculated for each fish size class. In both Monastir and Bizerte samples, the highest frequencies are clearly associated with the fish size classes that are below the mean class (Table 2). On the basis of the aforementioned observation, the total prevalence during the 2 or 3 yr period considered is estimated to be $72 \%$ for Monastir and $43 \%$ for Bizerte (Table 2).

An additional variable is the parasite charge (or infection intensity), i.e. the number of cysts per fish liver. Given that newly formed xenoma may be of a size below the detection limit, zero values are uncertain. The apparently uninfected fishes were therefore included within the low class of parasite charge, so that only the following 3 intervals were considered: $[0 ; 10[,[10 ; 30$ [ and $[30 ;+\infty$ [. All the individuals harboring at least 30 cysts belong to the 2 lower size classes (Table 2). Young fishes are, therefore, more susceptible to multiple infections.

\section{Life cycle stages}

The merogony of the parasite takes place in direct contact with the host cell cytoplasm and is characterized by the formation of near-spherical multinucleate plasmodia, with an average diameter of about $8 \mu \mathrm{m}$ (Fig. 2a). The cytoplasm is rich in rough endoplasmic reticulum (RER), and a maximum of 8 unpaired nuclei were counted on a section plane cut. Clusters of nuclei were sometimes observed. It is clear that the merogonic plasmodia are almost completely surrounded by host RER cisterna, the innermost membrane of which is tightly associated with the parasite plasma membrane (Fig. 2b,c).

The transition to sporogony is marked by the progressive disappearance of the peripheral host RER and the deposition of an electron-dense material onto the parasite plasma membrane. Sporonts are also represented by multinucleate plasmodia remaining in direct contact with host cytoplasm. Their shape and size are similar to those of meronts but their nuclei are more dispersed throughout the plasmodium (Fig. 3). Early sporoblasts correspond to small round cells of uniform size (mean diameter: $3 \mu \mathrm{m}$ ) (Fig. $4 \mathrm{a}, \mathrm{b})$. This suggests a rapid transition from the sporogonic plasmodium to the sporoblast stage via a simultaneous plasmotomic division process. The sporoblast evolves to an ovoid shape parallel to the development of an extensive intracellular membrane network and the deposition of large patches of exosporous material (Fig. 4c).

The final cell stage is an ovocylindrical spore (Fig. $5 \mathrm{a}-\mathrm{c}$ ) that measures $3.6 \times 1.2 \mu \mathrm{m}$ on average. Its anterior region contains the polaroplast that is exclusively of a lamellar type. The most packed membranes are found near the spore apex marked by the polar cap (or anchoring disk). Located at the centre of the spore, the nucleus is unique, spherical and surrounded by a concentric membrane array. The posterior vacuole is as large as the nucleus and extends close to a membranous body with coiled tubular elements (Fig. 5a,c). The polar tube forms 9 coils in its posterior part (Fig. 5a,c) and can be assigned to the isofilar type. The manubrium is rather long, forming an angle of about $32^{\circ}$ from the spore longitudinal axis (Fig. 5b). The exospore is thin and without ornaments. The electronlucid endospore has a thickness of $110 \mathrm{~nm}$ that is reduced to $55 \mathrm{~nm}$ at the spore apex (Fig. 5a,b). No sporophorous vesicle was observed.

\section{Formation of the focus of infection}

No external morphological signs of disease were visible in the infected fishes. At the macroscopic scale, a focus of infection appeared as a whitish, oval cyst that was generally connected with some blood vessels on the liver surface. These cysts were either isolated (Fig. 6) or clustered (Fig. 7). Two major stages in the evolution of the focus of infection, termed the xenoma and granuloma, are distinguished.

\section{Xenoma}

As a result of the considerable growth of an infected liver cell of an uncertain nature (cell type), the xenoma may attain up to $200 \mu \mathrm{m}$ in diameter, as shown by light microscopy of semi-thin sections. Because of their relatively small size, the visualization of xenomas required serial cross sectioning of fish liver pieces. Electron microscopy revealed that the parasite stages are randomly dispersed inside the enlarged host cell, with a hypertrophic and reticulate nucleus located at the periphery (Fig. 8). Early formed xenomas are surrounded only by the membrane of the infected host cell (Figs. 8 \& 9). Fairly large vesicles representing more or less swollen host mitochondria are also concentrated in the peripheral region (Fig. 9). The presence of fibrous ele- 


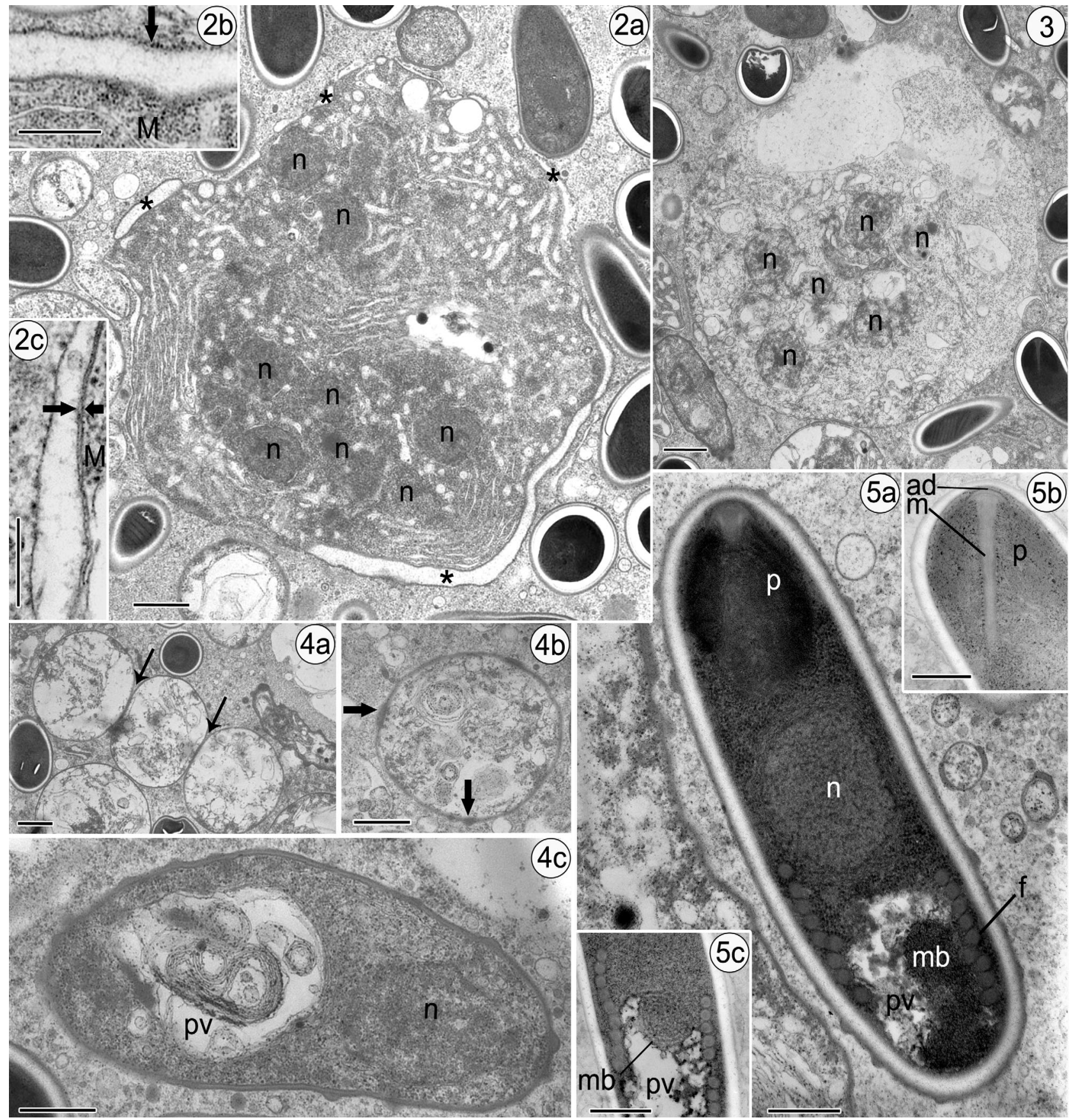

Figs. 2 to 5. Microgemma tincae n. sp. infecting Symphodus tinca. Transmission electron micrographs of the developmental stages of $M$. tincae n. sp. in liver cells of $S$. tinca. Fig. 2. Multinucleate merogonic plasmodium. The plasmodium is largely surrounded by cisternae of host rough endoplasmic reticulum (asterisks). Nuclei (n) form 2 distinct clusters. Higher magnification revealing the presence of ribosomes on the outer host membrane (arrow). M: merogonic cytoplasm. Close apposition of the inner host membrane to the merogonic plasma membrane (arrows). M: merogonic cytoplasm. Fig. 3. Multinucleate sporogonic plasmodium. n: nuclei. Fig. 4. Sporoblastic cells. A view of newly generated sporoblast, as suggested by the persistence of septa (arrows). Deposition of an outer electron dense material (arrows) and development of an extensive membranous network. Late sporoblastic stage, elongated in shape. The posterior vacuole (pv) begins to differentiate and the nucleus (n) occupies the opposite region. Concentric layers of membrane are abundant near the center of the future vacuole. Fig. 5. Ultrastructure of the mature spore. A spore with fully differentiated parts: lamellar polaroplast (p), nucleus (n), polar filament (f), posterior vacuole (pv). mb, membranous body. Anterior region showing the anchoring disc (ad), manubrium (m) and lamellar polaroplast (p) and membrane body. Presence of a membranous body $(\mathrm{mb})$ closely associated with the vacuole. Scale bars $=1 \mu \mathrm{m}$ in Figs. $2 \mathrm{a}, 3,4 \mathrm{a}, \mathrm{b}$, and $0.5 \mu \mathrm{m}$ in Figs. 2b,c, 4c \& 5 

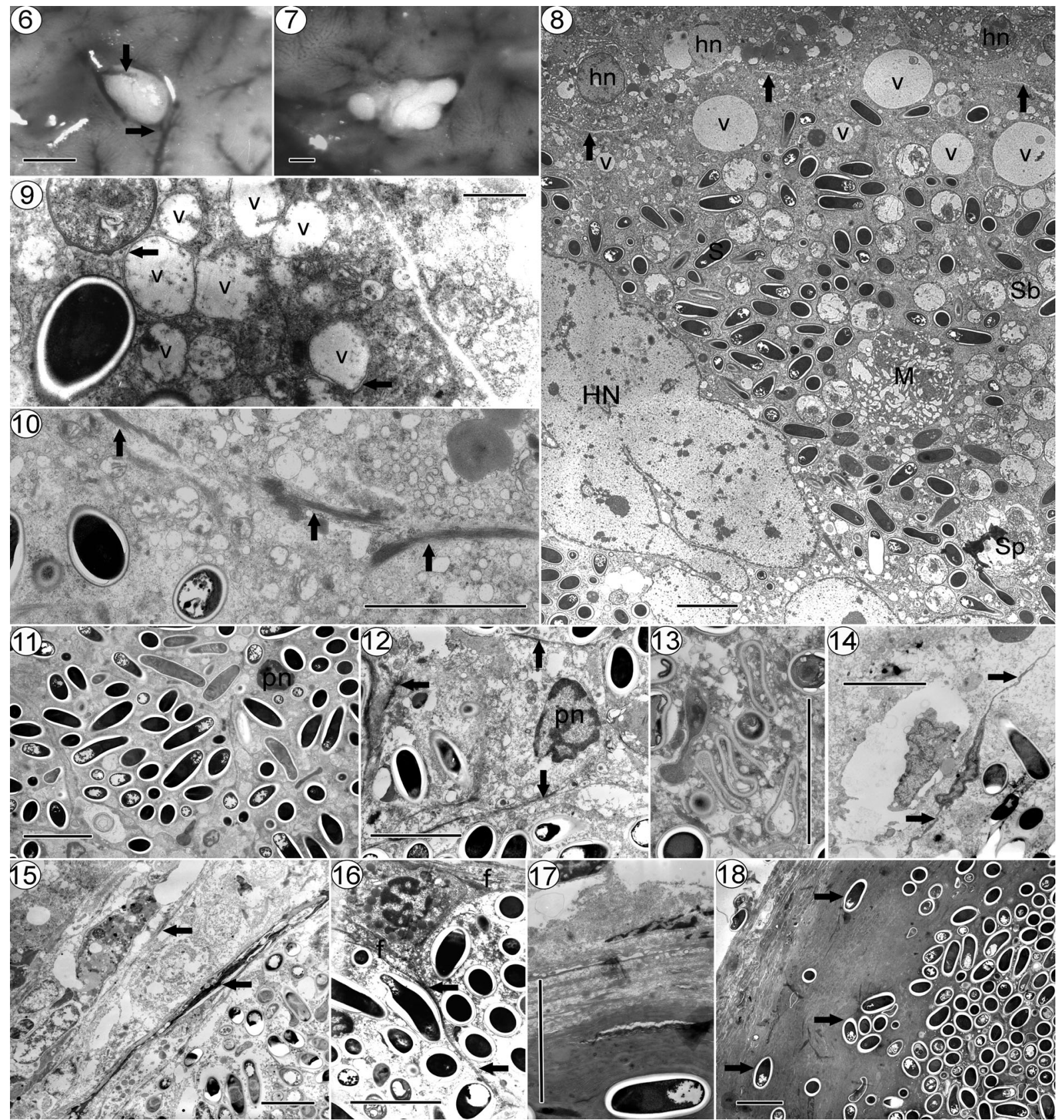

Figs. 6 to 18. Microgemma tincae focus of infection. Figs. 6 \& 7. Superficial views of foci of infection in Symphodus tinca liver. Fig. 6. A focus of infection formed by a single cyst. Arrows show the association with blood vessels. Fig. 7. A focus of infection composed of several cysts. Figs. 8 to 18. Electron micrographs of xenoma and granuloma structures. Fig. 8. Cross section of a xenoma. The hypertrophied nucleus (HN) of the infected cell strongly contrasts with the usual nuclei of uninfected cells (hn). The xenoma is bounded by a unique plasma membrane (arrows) and all parasite stages are spread randomly within the host cytoplasm. A large number of vesicles (v) accumulated toward the periphery. M: meront; Sp: sporont; Sb: sporoblast; S: spore. Fig. 9. Vesicles (v) with a double membrane (arrows) likely represent degenerated mitochondria. Fig. 10. Deposit of fibrous elements at the xenoma periphery (arrows). Fig. 11. Typical view of the granuloma interior. The compartmentalization results from the infiltration of phagocytic cells. Parasite stages other than spores are no longer recognizable. pn, phagocytic cell nucleus. Fig. 12. A phagocytic cell with some internalized spores, a nucleus of usual size (pn) and a thickened cell surface (arrows). Fig. 13. Spores at different stages of degeneration, some of which mainly retain the endospore material. Fig. 14. The onset of the formation of granuloma envelope is marked by cytoplasmic extensions of fibroblast cells (arrows). Fig. 15. Fibrous elements are progressively deposited (arrows). Fig. 16. Fibroblast cytoplasm (f) extends between hepatocytes and phagocytic cells. Fig. 17. Many fibrous layers form a very thick envelope. Fig. 18. Spores can be trapped in the envelope matrix (arrows). Scale bars $=1 \mathrm{~mm}$ in Figs. $6 \& 7,1 \mu \mathrm{m}$ in Fig. 9 and $5 \mu \mathrm{m}$ in 
ments near the xenoma plasma membrane (Fig. 10) is assumed to represent an early stage of host tissue response.

\section{Granuloma}

The development of the focus of infection involves an inflammatory response leading to a larger granuloma structure, up to $2 \mathrm{~mm}$ in diameter. Although it is somewhat difficult to determine the precise order of all the events, our electron micrographs of several granulomas suggest the occurrence of the following major phenomena: (1) infiltration of phagocytic cells, (2) progressive degradation of parasite stages, (3) formation of a thick envelope coat. Suggestive of macrophages, many cells with a simple nucleus exhibit large vacuoles that enclose more or less degraded parasite cells (Figs. 11 \& 12). Such phagocytic cells

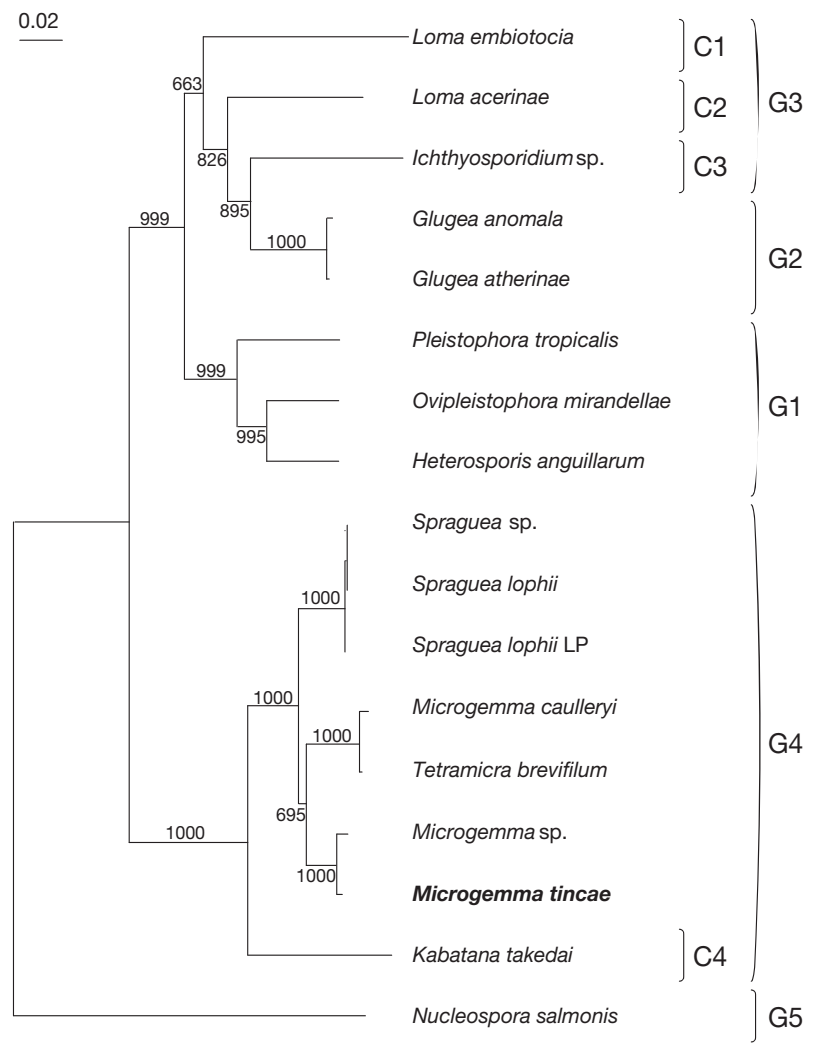

Fig. 19. Neighbor joining tree based on partial SSU rDNA (see Table 1) showing the close relationship between the microsporidian parasite of Symphodus tinca and Microgemma sp. within Group 4 of fish-infecting microsporidia (Tetramicriidae and Spragueidae). The bootstrap value is given for each node. Groups (G1 to G5) and clades (C1 to C4) numbered according to a recent exhaustive phylogenetic analysis (Lom \& Nilsen 2003) are represented on the right of the figure. The scale bar shows the number of changes per site are progressively surrounded by an electron-dense fibrous material (Fig. 12). The lack of evidence for plasmodia indicates a rapid destruction of the early stages of the parasite. Some degenerated late sporoblasts or spores can be seen in the form of wrinkled empty shells (Fig. 13). Thus, the central part of the granuloma tends to be enriched in more resistant mature spores. In addition to the deposition of dense material around all phagocytic cells, significant changes are mainly detected in the peripheral region of the granuloma (Figs. 14, 15, 16, 17 \& 18). A major consequence of the migration of numerous fibroblasts towards the focus of infection is the development of a thick coat $(20$ to $30 \mu \mathrm{m})$ containing several layers of fibrous elements that are commonly found within the extracellular matrix (Figs. $17 \& 18$ ). Spores may be trapped in the innermost and more compact part of the granuloma coat (Fig. 18).

\section{rDNA sequence comparison}

An 843-bp region of the SSU rRNA gene of the studied species was sequenced (GenBank accession number: AY651319). Multiple sequence alignment revealed strong identities with members of Group 4 defined by Lom \& Nilsen (2003), including 2 defined fish microsporidians representative of the 2 genera assigned to the family Tetramicriidae: Microgemma caulleryi (93\% identity) and Tetramicra brevifilum (95\% identity). The most closely related sequence was provided by the GenBank entry AJ252952 (direct submission by S. A. Cheney, 1999) that originates from an organism named Microgemma sp., but for which no morphological description is available. The phylogenetic tree generated by the NJ method confirms the clustering of the 2 species (Fig. 19). The bootstrap value (1000) gives high confidence to this result.

\section{DISCUSSION}

The only report of a microsporidian infecting Symphodus tinca is Ichthyosporidium hertwegi collected in the Black Sea (Swarcewsky 1914). A large structure (4 mm) containing smaller cysts (60 to $100 \mu \mathrm{m}$ ) was observed in the gills. Many features were in common with Ichthyosporidium giganteum, a parasite of another Symphodus species (S. melops). In both Ichthyosporidium species, early stages are monokaryotic amoeboid cells and sporogony is diplokaryotic (Swarcewsky 1914). This is not the case in the microsporidian that formed cysts in the liver of $S$. tinca specimens.

There was a fairly high prevalence among fishes captured in the Mediterranean Sea near Monastir and 
Bizerte (Tunisia). Small specimens were the most frequently infected and exhibited the highest parasite load. Thus, although we did not examine younger fishes (below $12 \mathrm{~cm}$ in length), it seems likely that juveniles are very sensitive to microsporidian infection. The low frequency of cysts in classes of large specimens may reflect either a selective advantage of fishes that have never been infected or an increasing resistance to primary and/or secondary infections during fish growth. The second possibility is supported by cytological evidence for granuloma formation. The host response expressed by xenoma to granuloma conversions might become sufficiently efficient in adult fishes to stop parasite proliferation. Differences in the frequency of infected fishes and parasite charge between the 2 fishing sites may be due to differences in sampling. Some external factors may also be involved. It is noteworthy that the Bizerte coast is open to the Mediterranean Sea and presents a low level of pollution, in contrast to the Monastir coast. We hypothesize that pollution favors repeated microsporidian infections. Some pollutant stressors are known to enhance the susceptibility of hosts to various parasites (Yeomans et al. 1997, Williams \& MacKenzie 2003). In a recent study, multifocal xenomas of Glugea stephani were frequently observed in fishes captured in 2 bays near contaminated sites in western Newfoundland (Khan 2004).

The periphery of the xenoma induced by the microsporidian infecting Symphodus tinca displayed only a plasma membrane coated with a thin fibrous layer. This is quite different from Glugea xenomas which are characterized by the formation of a thick wall comprising multiple layers of a glycoprotein material secreted by the infected cell (Canning et al. 1982). No microvilli-like projections were observed in contrast to xenomas due to Tetramicra brevifilum (Matthews \& Matthews 1980), Microgemma hepaticus (Ralphs \& Matthews 1986) and Microfilum lutjani (Faye et al. 1991). Numerous mitochondria were packed within a peripheral cytoplasmic region as in Microgemma hepaticus (Ralphs \& Matthews 1986) and $M$. ovoidea (Amigó et al. 1998). From our observations, we can deduce that most large cysts in the liver of $S$. tinca are the visible expression of xenoma to granuloma conversions involving the infiltration of macrophages and recruitment of fibroblasts. Similar host responses have been reported for fish infections due to various microsporidia such as Glugea anomala (Dykova \& Lom 1978), Spraguea lophii (Dykova \& Lom 1980), T. brevifilum (Matthews \& Matthews 1980) and 3 Microgemma species (Ralphs \& Matthews 1986, Amigó et al. 1998, Leiro et al. 1999). However, it should be recalled that granuloma formation in fish hosts can be related to infections by several other organisms including mycobacteria (Gauthier et al. 2003), coccidia (Eaton et al. 1991), parasitic fungi (Lilley et al. 2003, Johnson et al. 2004) and nematodes such as Anguillicola crassus (Székely et al. 1996). Microsporidian stages were extensively degraded within a cyst that progressively acquired a thick envelope. However, the cluster structure of some individual foci of infection and the existence of multiple foci suggest that some spores may escape degradation. During envelope formation, phagocytic cells can release spores, as thoroughly described in $M$. ovoidea (Amigó et al. 1998).

All developmental stages of the Symphodus tinca parasite were observed to lie in direct contact with the host cell cytoplasm and to have unpaired nuclei. No sporophorous vesicles are formed. Meronts and sporonts are multinucleate plasmodia that divide by plasmotomy. The meront is typically surrounded by host RER. Its direct transformation into sporont is marked by the loss of the host RER-parasite interface, as well as by the appearance of the peripheral dense material assimilated to the future exospore. Such characters suggest that the species could be assigned to the genus Microgemma (family Tetramicriidae). Three Microgemma species have been previously characterized, all growing in fish liver cells: $M$. hepaticus Ralphs \& Matthews, 1986, a parasite of the grey mullet (Ralphs \& Matthews 1986); M. ovoidea Thélohan, 1895, a parasite of the red band fish (Amigó et al. 1996); and M. caulleryi Van den Berge, 1949, a parasite of the greater sand-eel (Leiro et al. 1999). In these 3 species, sporonts divide by a combination of budding and plasmotomy to give sporoblasts. Unfortunately, we failed to gain informative images of intermediate division stages in the $S$. tincainfecting species. As all the sporoblasts are of a similar size, we assume that simultaneous plasmotomy is the major process. Significant differences in host cellmeront interface exist among Microgemma species. As for the parasite of $S$. tinca, host RER cisternae surround the meronts of $M$. caulleryi (Leiro et al. 1999), but not those of M. ovoidea (Amigó et al. 1996). The $M$. hepaticus case with meronts enclosed within host RER lumen is remarkable (Ralphs \& Matthews 1986). The membranous body located close to the posterior vacuole of young and mature spores has also been described in Tetramicra brevifilum (Matthews \& Matthews 1980). However, this structure, called a posterosome (Weiser \& Žižka 1975), is likely present in various microsporidia, including mammal-infecting species such as Encephalitozoon cuniculi (Pakes et al. 1975). A Golgi origin has been suggested (Vavrá \& Larsson 1999). We think that neither RER-derived interface nor posterosome are relevant criteria for species classification. 
We tend to exclude an assignation to the morphologically similar genus Tetramicra, only represented by the species $T$. brevifilum, which commonly infects the turbot (Estévez et al. 1992) but can be also found in the black anglerfish (Maíllo et al. 1998). Microgemma sporogony is indeed polysporoblastic, whereas Tetramicra sporogony is tetrasporoblastic (Matthews \& Matthews 1980). However, the grouping of $T$. brevifilum with Microgemma caulleryi in phylogenetic SSU rDNA trees generated by the maximum likehood method (Lom \& Nilsen 2003), as well as in our analysis by the NJ method, is somewhat surprising. Do the direct transition from merogonic to sporogonic plasmodia in Microgemma and the regular presence of tetranucleate sporonts in Tetramicra represent significant discrimination criteria at the generic level? Is $M$. caulleryi really more structurally similar to other Microgemma species than to T. brevifilum? With respect to the first question, the origin and mode of division of sporogonic plasmodia are known to be diverse among microsporidia and indeed appear as useful characters for taxonomy. The relative importance of the discrimination between 'tetrasporoblastic' and 'polysporoblastic' is debatable, however. Formerly named Glugea caulleryi, the parasite of the greater sand-eel was transferred to the genus Microgemma, mainly because of the lack of sporophorous vesicles and the occurrence of a polysporoblastic sporogony that forms separate sporoblasts by exogenous budding (Leiro et al. 1999). The number of sporoblasts has not been mentioned and cannot be deduced from the examination of published electron micrographs. Thus, uncertainties in the description of $M$. caulleryi sporogonic division leave the question open as to whether $M$. caulleryi and $T$. brevifilum belong to different genera or not. Unfortunately, the finding that the parasite of Symphodus tinca is the closest relative of Microgemma sp., on the basis of our comparison of partial SSU rDNA sequences, cannot be correlated with morphological data. The only information available for the aforementioned putative Microgemma species is indeed its isolation from the liver of the long-spined sea scorpion Taurulus bubalis, as mentioned in a study focusing on phylogenetic relationships between Pleistophora-like species (Cheney et al. 2000). It is hoped that SSU rDNA from Microgemma hepaticus and Microgemma ovoidea will be further sequenced to help to develop a better resolution of possible distinct clades within the family Tetramicriidae and a better evaluation of the structural criteria used to distinguish at least two genera. Based on the current level of our knowledge, it seems reasonable to consider that the microsporidian found in the liver of Symphodus tinca is a Microgemma species.

\section{DIAGNOSIS OF MICROGEMMA TINCAE NOV. SP.}

Locality. Tunisian coasts, Mediterranean Sea (prevalence: 43 to $72 \%$ )

Host and site of infection. Symphodus (Crenilabrus) tinca (Linnaeus, 1758); liver.

Lesion. Whitish xenomas up to $200 \mu \mathrm{m}$ (granulomas in old infection).

Development. Nuclei are unpaired in all development stages.

Merogony: Multinucleate meronts divide by plasmotomy, are surrounded by host RER and enter directly to sporogony.

Sporogony: Multinucleate plasmodia sporonts are rounded in shape, in direct contact with host cell cytoplasm and divide by plasmotomy, producing spherical sporoblastic cells. Sporoblasts are also in direct contact with host cell cytoplasm.

Spores: Uninucleate and ovocylindrical, mean size of $3.6 \mu \mathrm{m} \times 1.2 \mu \mathrm{m}$. Polaroplast is exclusively lamellar. Isofilar polar tube (9 coils). Vacuole, in the posterior third of the spore, is associated with a tubular membranous body.

Signature sequences. Pair-wise sequence variation between $M$. tincae and Microgemma sp. sequence represents about $1 \%$, corresponding to the insertion of an $\mathrm{AC}$ dinucleotide (positions 24 to 25) in $M$. tincae and to 3 base substitutions (3 A/G transitions in positions 224, 230 and 489; 3 transversions in positions 823, 835 and 836). Only the 2 last substitutions are characteristic of $M$. tincae.

Remarks. The site of infection in the host and description of the onset of parasite development (merogony to mid-sporogony) are strong criteria for the placement of the microsporidian infecting Symphodus tinca in the genus Microgemma. The contention that this is a new species is supported by the cytological features at the end of the sporogony (division of the sporont in sporoblasts) and rDNA phylogenetic analysis.

Acknowledgements. This work was supported by the CMCU grant 02F0920.

\section{LITERATURE CITED}

Amigó JM, Salvadó H, Gracia MP, Vivarès CP (1996) Ultrastructure and development of Microsporidium ovoideum (Thél. 1895) Sprague, 1977, a microsporidian parasite of the red band fish (Cepola macrophthalma L.). Redescription of the organism and reassignment to the genus Microgemma, Ralphs \& Matthews 1986. Eur J Protistol 32: $532-538$

Amigó JM, Salvado H, Gracia MP (1998) The pathologic cycle of the infection of the microsporidian Microgemma ovoidea (Thel., 1895) Amigó et al. 1996 in the liver of the Red Band Fish (Cepola macrophthalma L.). Parasitol Res $84: 7-12$ 
Azevedo C, Matos E (2003) Amazonspora hassar n. gen. and n. sp. (phylum Microsporidia, fam. Glugeidae), a parasite of the Amazonian teleost Hassar orestis (fam. Doradidae). J Parasitol 89:336-341

Berrebi P, Bouix G (1978) Premières observations sur une microsporidiose de l'athérine des étangs languedociens, Atherina boyeri Risson, 1810 (poisson, Téléostéen). Ann Parasitol Hum Comp 53:1-20

Bryan RT, Schwartz DA (1999) Epidemiology of microsporidiosis. In: Wittner M, Weiss LM (eds) The Microsporidia and Microsporidiosis. ASM Press, Washington, DC, p 502-516

Canning EU, Nicholas JP (1980) Genus Pleistophora (Phylum Microspora): redescription of the type species, Pleistophora typicalis Gurley, 1893 and ultrastructural characterization of the genus. J Fish Dis 3:317-338

Canning EU, Lom J, Nicholas JP (1982) Genus Glugea Thelohan, 1891 (Phylum Microspora): redescription of the type species Glugea anomala (Moniez, 1887) and recognition of its sporogonic development within sporophorous vesicles (pansporoblastic membranes). Protistologica 18: 193-210

Cheney SA, Lafranchi-Tristem NJ, Canning EU (2000) Phylogenetic relationships of Pleistophora-like microsporidia based on small subunit ribosomal DNA sequences and implications for the source of Trachipleistophora hominis infections. J Eukaryot Microbiol 47:280-287

Durbin R, Mieg JT (1991) A Caenohabditis elegans database. Documentation code and data available from anonymous FTP servers at lirmm.lirmm.fr, cele.mrc-lmb.cam.ac.uk, ncbi.nlm.nih.gov and www.acedb.org

Dyková I, Lom J (1978) Tissue reaction of the three-spined stickleback Gasterosteus aculeatus L. to infection with Glugea anomala (Moniez, 1887). J Fish Dis 1:83-90

Dyková I, Lom J (1980) Tissue reaction to microsporidian infection in fish hosts. J Fish Dis 3:265-283

Eaton WD, Kent ML, Meyers TR (1991) Coccidia, X-cell pseudotumors and Ichthyophonus sp. infections in walleyepollock (Theregra chalcogramma) from Auke Bay, Alaska. J Wildl Dis 27:140-143.

Estévez J, Iglesias R, Leiro J, Ubeira FM, Sanmartin ML (1992) An unusual site of infection by microsporean in the turbot Scophtalmus maximus. Dis Aquat Org 13:139-142

Faye A, Toguebaye BS, Bouix G (1991) Microfilum lutjanin.g. n.sp. (Protozoa Microsporida), a gill parasite of the golden African snapper Lutjanus fulgens (Valenciennes, 1830) (Teleostei, Lutjanidae): developmental cycle and ultrastructure. J Protozool 38:30-40

Gauthier DT, Rhodes MW, Vogelbein WK, Kator H, Ottinger CA, Khan RA (2003) Experimental mycobacteriosis in striped bass Morone saxatilis. Dis Aquat Org 54:105-17

Johnson RA, Zabrecky J, Kiryu Y, Shields JD (2004) Infection experiments with Aphanomyces invadans in four species of estuarine fish. J Fish Dis 27:287-295

Khan RA (2004) Effect, distribution, and prevalence of Glugea stephani (Microspora) in winter flounder (Pleuronectes americanus) living near two pulp and paper mills in Newfoundland. J Parasitol 90:229-233

Larsson JIR (1999) Identification of Microsporidia. Acta Protozool 38:161-197

Leiro J, Paramá A, Ortega M, Santamarina MT, Sanmartin ML (1999) Redescription of Glugea caulleryi, a microsporidian parasite of the greater sand-eel, Hyperoplus lanceolatus (Le Sauvage), (Teleostei: Ammodytidae), as Microgemma caulleryi comb. J Fish Dis 22:101-110

Lilley JH, Hart D, Panyawachira V, Kanchanakhan S, Chinabut S, Soderhall K, Cerenius L (2003) Molecular characterization of the fish-pathogenic fungus Aphanomyces invadans. J Fish Dis 26:263-275

Lom J (2002) A catalogue of described genera and species of microsporidians parasitic in fish. Syst Parasitol 53:81-99

Lom J, Nilsen F (2003) Fish microsporidia: fine structural diversity and phylogeny. Int J Parasitol 33:107-27

Lom J, Dyková I, Tonguthai K (1999) Kabataia gen. n., a new genus proposed for Microsporidium spp. infecting trunk muscles of fishes. Dis Aquat Org 38:39-46

Lom J, Dyková I, Tonguthai K (2000) Kabatana gen. n., new name for the microsporidian genus Kabataia Lom, Dykova et Tonguthai, 1999. Folia Parasitol (Praha) 47:78

Loubès C, Maurand J, Ormières R (1979) Etude ultrastructurale de Spraguea lophii (Doflein, 1898) microsporidie parasite de la Baudroie: essai d'interprétation du dimorphisme sporal. Protistologica 15:43-54

Maíllo PA, Amigó JM, Baena R, Salvadó H, Garcia MP (1998) Tetramicra brevifilum (Matthews \& Matthews, 1980) (Microsporidia Tetramicriidae) in a new fish host, Lophius budegassa (Spinola, 1807) in Spain. Parasitol Res 84: 208-212

Matthews RA, Matthews BF (1980) Cell and tissue reactions of turbot Scophthalmus maximus (L.) to Tetramicra brevifilum gen.n., sp.n. (Microspora). J Fish Dis 3:495-515

Moniez R (1887) Observation pour la révision des microsporidies. C R Acad Sci III 104:1312-1314

Morrison CM, Sprague V (1981) Electron microscope study of a new genus and new species of microsporidia in the gills of the Atlantic cod Gadus morhua L. J Fish Dis 4:15-32

Pakes SP, Shadduck JA, Cali A (1975) Fine structure of Encephalitozoon cuniculi from rabbits, mice and hamsters. J Protozool 22:481-488

Pekkarinen M, Lom J, Nilsen F (2002) Ovipleistophora gen. $\mathrm{n}$., a new genus for Pleistophora mirandellae-like microsporidia. Dis Aquat Org 48:133-142

Ralphs JR, Matthews RA (1986) Hepatic microsporidiosis due to Microgemma hepaticus $\mathrm{n}$. gen., n. sp. in juvenile grey mullet Chelon labrosus. J Fish Dis 9:225-242

Shaw RW \& Kent ML (1999) Fish microsporidia. In: Wittner M and Weiss LM (eds) The Microsporidia and microsporidiosis. ASM Press, Washington, DC, p 502-516

Swarczewsky B (1914) Über den Lebenszyklus einiger Haplosporidien. Arch Protistenkd 33:49-108

Székely C, Pazooki J, Molnár K (1996) Host reaction in paratenic fish hosts against 3rd stage larvae of Anguillicola crassus. Dis Aquat Org 26:173-180

Thompson JD, Higgins DG, Gibson TJ (1994) CLUSTAL W: improving the sensitivity of progressive multiple sequence alignment through sequence weighting, position-specific gap penalties and weight matrix choice. Nucleic Acids Res 11:4673-4680.

Vavrá J, Larsson JIR (1999) Structure of Microsporidia. In: Wittner M, Weiss LM (eds) The Microsporidia and microsporidiosis. ASM Press. Washington, DC, p 7-84

Weiser J, Žižka Z (1975) Stages in sporogony of Pleistophra debaisieuxi J?rovec (Microsporidia). Acta Protozool 14: 185-194

Weiss LM, Vossbrinck CR (1998) Microsporidiosis: molecular and diagnostic aspects. Adv Parasitol 40:351-395

Weissenberg R (1949) Cell growth and cell transformation by intra-cellular parasites. Anat Rec 103:517-518

Williams HH, MacKenzie K (2003) Marine parasites as pollution indicators: an update. Parasitology 126 Suppl: S27-41

Yeomans WE, Chubb JC, Sweeting RA (1997) Use of protozoan communities for pollution monitoring. Parassitologia 39:201-212 